\title{
Lectotypification of the names of four species in Sonerila (Melastomataceae)
}

\author{
Resmi S. \& Santhosh Nampy* \\ Department of Botany, University of Calicut, Malappuram District, Kerala - 673 635, India \\ *E-mail: santhoshnampy2019@gmail.com
}

\begin{abstract}
Four names in Sonerila Roxb. (Melastomataceae) viz., S. arguta, S. grandiflora, S. pulneyensis and S. squarrosa are lectotypified here.
\end{abstract}

Keywords: Lectotype, Nomenclature, Sonerila arguta, S. grandiflora, S. pulneyensis, S. squarrosa.

\section{Introduction}

The genus Sonerila Roxb. (Melastomataceae) with approximately 180 taxa is distributed in the IndoPacific regions (Cellinese, 1997) and includes 58 species and two varieties in India (Resmi et al., 2018).

During a revisionary study on Sonerila in India, it is found that lectotypification is necessary for many names because it could not be made clear that only a single specimen was used by the author. Furthermore, according to McNeill (2014) citation of a single collection number often housed in more than one institution are to be treated as syntypes.

Resmi and Nampy (2018) designated lectotypes of four names in Sonerila, viz., S. rotundifolia Bedd., $S$. scapigera Hook., S. versicolor Wight and S. wallichii Benn. In this paper, lectotypes are designated for another four names, viz., S. arguta R.Br. ex Naudin, $S$. grandiflora R.Br. ex Wight \& Arn., S. pulneyensis Gamble and S. squarrosa Wall. according to Art. 9.3 of the Shenzhen Code (Turland et al., 2018).

Sonerila arguta R.Br. ex Naudin, Ann. Sci. Nat. Bot. ser. 3, 15 (4): 326.1851. Lectotype (designated here): BANGLADESH/INDIA, Mount Sillet

Received: 30.06.2019; Revised \& Accepted: 20.09.2019

Published Online: 31.12.2019
[Sylhet/Meghalaya], s.d., FD [F.De Silva], Wallich Numer. List 4095 (G00319884 digital image!). Fig. 1

Nomenclatural notes: Brown in the year 1831 proposed S. arguta in the Wallich catalogue (18281849) as “4095, Sonerila arguta Brown, Mount Sillet FD” [Mount Sylhet, F. De Silva] but the name was not validly published. Naudin (1851) subsequently validated the name, citing "In monte Sillet Indiæ; Wallich, n. 4095”. According to TL-2 (Stafleu \& Cowan, 1981), the herbarium and type material of

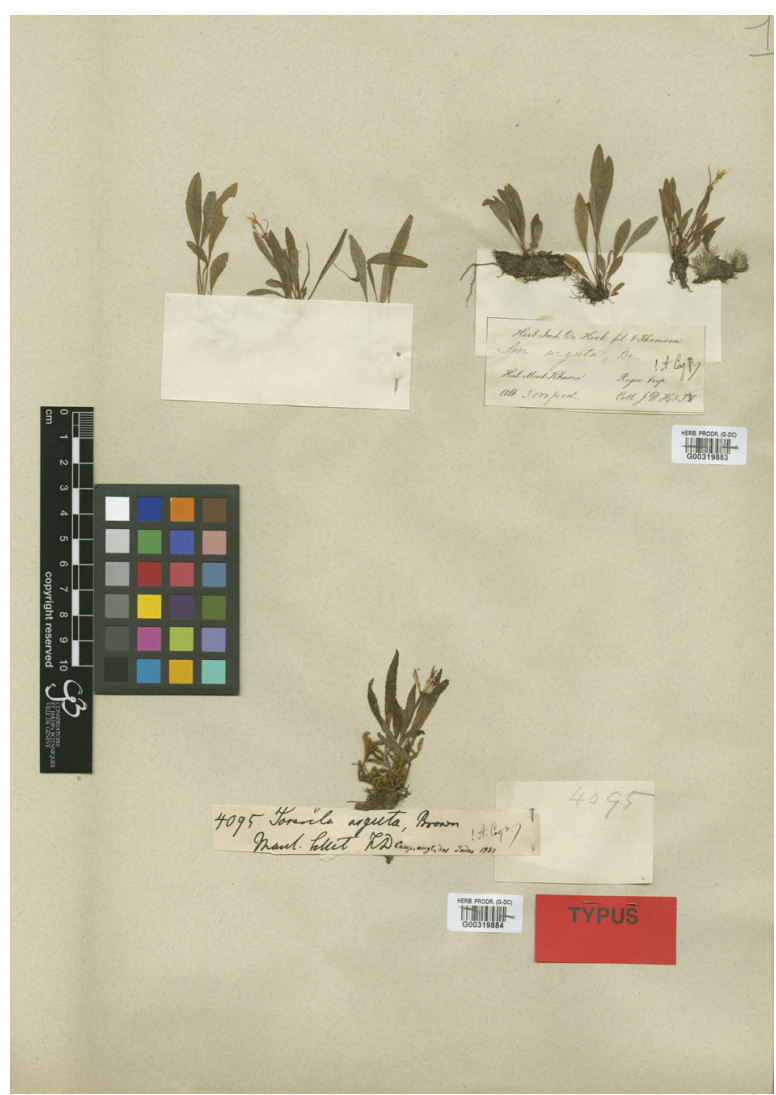

Fig. 1. Lectotype of Sonerila arguta (G00319884). (C) The Board of Trustees for the Conservatoire et Jardin botaniques de la Ville de Genève, Geneva. Reproduced with permission. 
Naudin, Charles Victor (1815-1899) are at A, G, K and $\mathrm{P}$. We have traced four relevant Wallichian collections at K (K000867660, K000867661, $\mathrm{K} 000867662$, K001038121) and one at G (G00319884), but none in P and A. Also, we found three specimens at E (E00288115, E00288116, E00288117) and one at NY (NY00273279), but not sure whether they have been consulted by Naudin. We select the specimen at G (G00319884) as the lectotype which has the annotation "4095 Sonerila arguta Brown, Mont Sillet, FD” and best represents the species. There is a problem associated with ascribing "Silhet" collections either Bangladesh or India (Meghalaya) as this locality is ambiguously used in the Wallich Catalogue (Clarke, 1913).

Sonerila grandiflora R.Br. ex Wight \& Arn., Prodr. Fl. Ind. Orient. 322. 1834. Lectotype (designated here): INDIA, South India, Nilgiri, s.d., s.coll. Wallich Numer. List 4099 (K001038128 digital image!).

Fig. 2

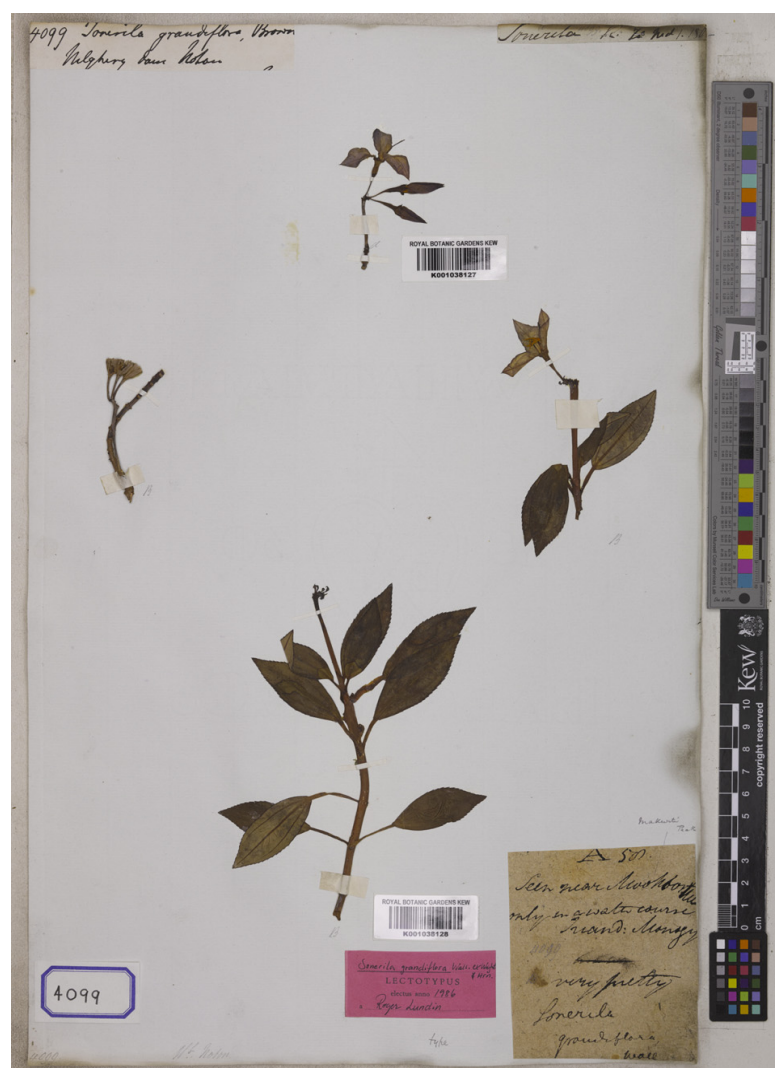

Fig. 2. Lectotype of Sonerila grandiflora (K001038128). (C) The Board of Trustees for the Royal Botanic Gardens, Kew. Reproduced with permission.
Nomenclatural notes: The name S. grandiflora was first proposed by Brown in 1831 in the Wallich Catalogue (1828-1849) against Numer. List 4099 and quoted "Sonerila grandiflora Brown, Nelghery dam, Noton" but it was not validly published. Wight and Arnott (1834) subsequently validated the name based on collection of Noton. Noltie (2005) gave the type details as 'Wall. Cat. 4099. Neelgherries-Noton. No specimens at E'. We traced three relevant specimens at K (K000567347, K001038127, K001038128) that matched the protologue. The barcode K000567347 has three flowering twigs and the annotation of Wallich "Sonerila grandiflora, Nelghery, Wallich 1831,.... 4099". The other sheet has four specimens numbered A and B, respectively assigning two barcodes K001038127 and K001038128. K001038127 has a flowering twig and an annotation “4099, S. grandiflora Brown, Nelghery dam, Noton” whereas K001038128 has three flowering/ fruiting specimens and an annotation "4099, Noton" and a label "seen near Mukurthy Peak only in a watercourse....... Sonerila grandiflora". This label was presumably written by the collector Benjamin Noton, who in the period 1825-1826 collected mainly in the Nilgiri Hills. We chose K001038128, the best representative of the species, as the lectotype.

Sonerila pulneyensis Gamble, Bull. Misc. Inform. Kew 1919 (5): 226. 1919. Lectotype (designated here): INDIA, Tamil Nadu, Pulney hills, Pambar ravine, Sir A.G. \& Lady Bourne 1341 (K000867653 digital image!).

Fig. 3

Nomenclatural notes: Within the protologue of $S$. pulnyensis, Gamble (1919) provided a note: "South India, Pulney hills, in the Pambar ravine, June, 1899, Sir A. [Sir A.G.] and Lady Bourne 1341" after the morphological description. We traced three relevant specimens at K (K000867653, K000867654, K000867655) matching with the description and specimen label information (Herbarium of Sir A.G. and Lady Bourne, Presented July 1915) included in the protologue. All the three sheets also carry annotation "Pambar stream, Pulneys/Pambar Ravine-Pulneys, 28 June 1899” and Bourne 1341". 


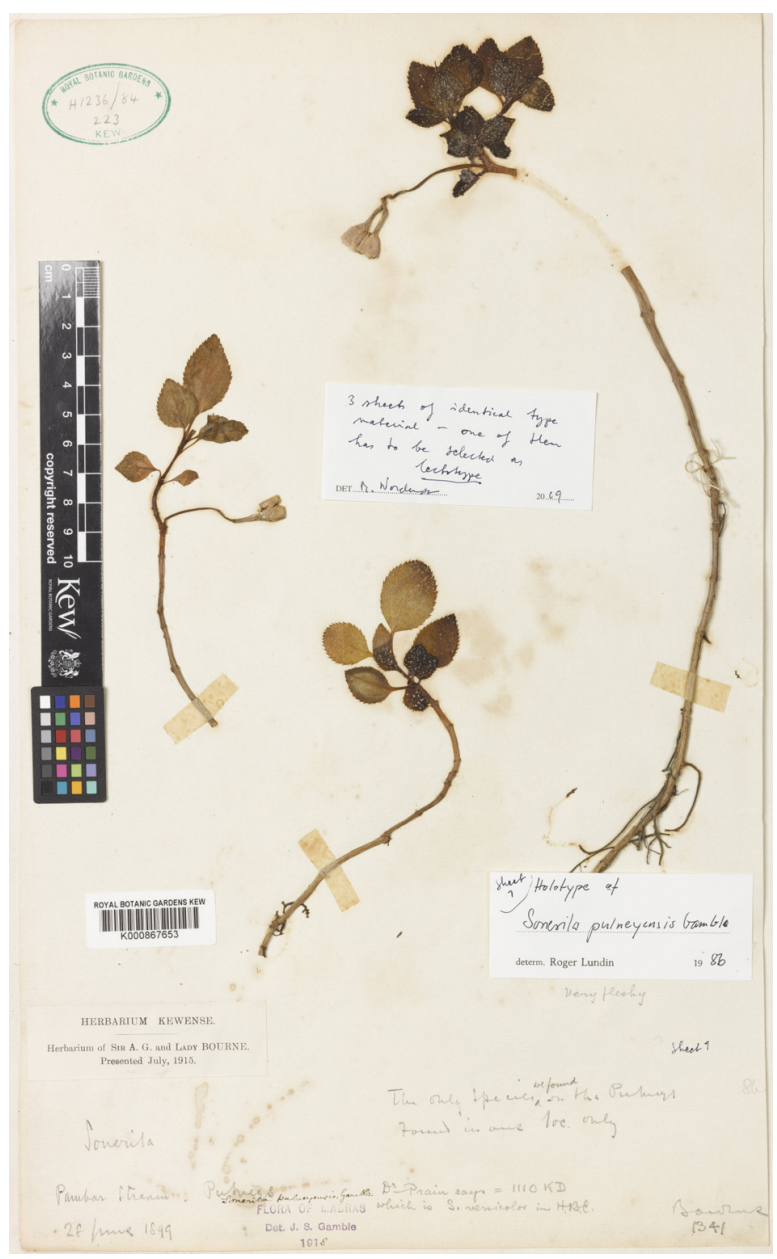

Fig. 3. Lectotype of Sonerila pulnyensis (K000867653). (C) The Board of Trustees for the Royal Botanic Gardens, Kew. Reproduced with permission.

The sheet K000867653 is here designated as the lectotype as it best represents the protologue.

Sonerila squarrosa Wall. in Roxb., Fl. Ind. 1: 182. 1820. Lectotype (designated here): INDIA, Assam, s.loc., s.d., Wallich s.n. (K000867680A, digital image!)

Fig. 4

Nomenclatural notes: In the protologue of S. squarrosa (in Roxburgh 1820: 182) a note says "Growing among ferns on the Khassee mountains.......". It was further mentioned "I received this pretty little plant from my indefatigable and zealous assistant, Mr. Smith at Silhet in 1817". The materials of Smith are, however, not available in any herbaria. In Wallich catalogue (1828-1849) it is cited "4093 Sonerila squarrosa Wall., Mount Sillet FD"[Mount Sylhet, F. De Silva]. The main

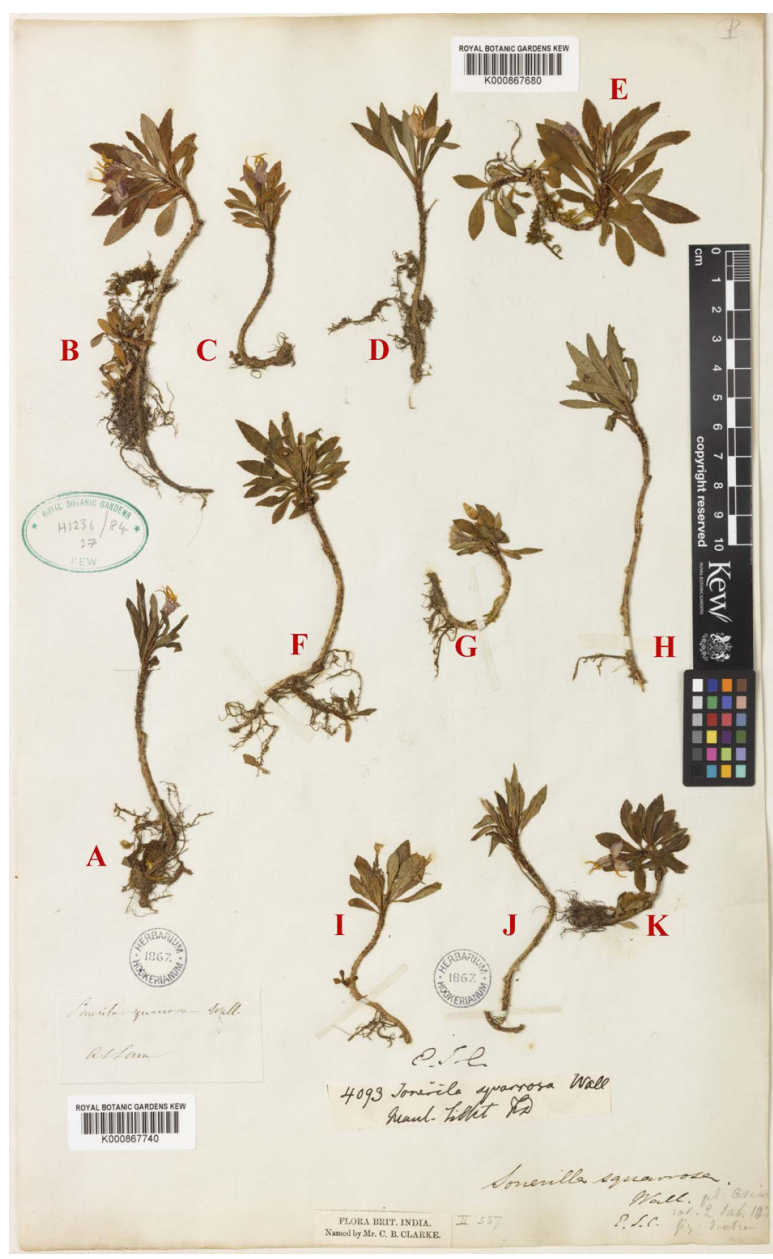

Fig. 4. Lectotype of Sonerila squarrosa (K000867680A). (C) The Board of Trustees for the Royal Botanic Gardens, Kew. Reproduced with permission.

set of Wallich's collections (including types) is known to be at K and K-W (Stafleu \& Cowan, 1988). We have traced three relevant Wallichian collections at K. The sheet K001038119 carries six specimens and three labels, two are matching with the Wallich handwriting ("4093 Sonerila squarrosa Wall., Mount Sillet FD" and "Sonerila squarrosa Wall, E montibus Pundua" ?) and the other one is uncertain (“Cherapunjee, September 1829"). Eleven plants from two locations were mounted on the other sheet and assigned two barcodes K000867680 and K000867740. The specimens are numbered A to $\mathrm{K}$ for the purpose of lectotypification. 'A' belongs to K000867740 bearing the label "Sonerila squarrosa Wall., Assam” and B to K belong to K000867680 bearing the annotation "EIC [East India Company]", and the Wallich's label "4093 Sonerila 
squarrosa Wall, Mount Sillet FD”. The sheet $\mathrm{K} 000867680$ (A) is chosen here as the lectotype as it agrees with the protologue.

\section{Acknowledgements}

The authors are thankful to The Head, Department of Botany, University of Calicut, for facilities; the Curators of $\mathrm{K}$ and $\mathrm{G}$ for permission to use the digital images of type specimens; Dr. Mark F. Watson, Head of Major Floras, Royal Botanic Garden, Edinburgh, who heads the Wallich Catalogue online project and Dr. Heleen Plaisier, Assistant Herbarium curator, RBG, Edinburgh, for resolving the doubts about the annotations of the collectors. We would like to thank Dr. K.N. Gandhi (Senior Nomenclatural Registrar, Harvard University) for clarifying the doubts on the author citation.

\section{Literature Cited}

CELLINESE N. 1997. Notes on the systematics and biogeography of the Sonerila generic alliance (Melastomataceae) with special focus on fruit characters. Tropical Biodiversity 4(1): 83-93.

CLARKE C.B. 1913. Notes on the Khasia localities of Wallich's List. Bulletin of miscellaneous information, Royal Gardens, Kew 7: 255-262.

GAMBLE J.S. 1919. Decades Kewenses: Regi conservatarum XCII \& XCIII. Bulletin of Miscellaneous information, Royal Gardens, Kew 5: 226.

MCNEILL J. 2014. Holotype specimens and type citations: General issues. Taxon 63(5): 1112-1113.

NAUDIN C.V. 1851. Melastomatacearum quae in Musaeo Parisiensi continentur monographicae descriptionis. Annales des Sciences Naturelles Botanique, serie 3, 15(4): 326.
NOLTIE H.J. 2005. The Botany of Robert Wight. A.R.G. Gantner Verlag K.G. p. 348.

RESMI S. \& S. NAMPY 2018. Lectotypification of four names in Sonerila (Melastomataceae). Phytotaxa 375 (2): 165-170. https://doi.org/10.11646/phytotaxa.375.2.3

RESMI S., MANUDEV K.M., PRAMOD C. \& S. NAMPY 2018. A new species of Sonerila (Melastomataceae: Sonerileae) from southern Western Ghats, India. Phytotaxa 333(2): 235-242. https://doi.org/10.11646/ phytotaxa.333.2.7

ROXBURGH W. 1820. Flora Indica. (ed. Carey) Volume 1. Serampore, India. pp. 180-183.

STAFLEU F.A. \& R.S. COWAN 1981. Taxonomic literature: A selective guide to botanical publications and collections with dates, commentaries and types, Second Edition, Volume 3: Lh-O. Regnum Vegetabile 105. Bohn, Scheltema \& Holkema, Utrecht. https://doi.org/10.5962/bhl.title.48631

STAFLEU F.A. \& R.S. COWAN 1988. Taxonomic literature: A selective guide to botanical publications and collections with dates, commentaries and types, Second Edition, Volume 7: W-Z. Regnum Vegetabile 116. Bohn, Scheltema \& Holkema, Utrecht.

TURLAND N.J., WIERSEMA J.H., BARRIE F.R., GREUTER W., HAWKSWORTH D.L., HERENDEEN P.S., KNAPP S., KUSBER W.H., LI D.Z., MARHOLD K., MAY T.W., MCNEILL J., MONRO A.M., PRADO J., PRICE M.J. \& G.F. SMITH (Eds.) 2018. International Code of Nomenclature for algae, fungi, and plants (Shenzhen Code) adopted by the Nineteenth International Botanical Congress, Shenzhen, China, July 2017. Regnum Vegetabile 159. Koeltz Botanical Books, Glashütten. p. 254. https://doi.org/ 10.12705/Code.2018.

WALLICH N. 1828-1849. A Numerical List of dried specimens of plants in the East India Company's Museum. London.

WIGHT R. \& G.A.W. ARNOTT 1834. Prodromus Florae Peninsula Indiae orientalis: Containing Abridged Descriptions of the Plants found in the Peninsula of British India, Arranged According to the Natural System, Volume 1. Parbury, Allen \& Co., London. p. 321. 